\title{
Synthesis and Biological Activity of Analogs of Substance P, Modified for Conformational Information by D-Amino Acids
}

\author{
ISOMARO YAMAGUCHI, ${ }^{a}$ GERHARD RACKUR,a JOHANN J. LEBAN,,a ULLA BJÖRKROTH, \\ SUNE ROSELL ${ }^{b}$ and KARL FOLKERS $a$,*
}

a Institute for Biomedical Research, The University of Texas at Austin, Austin, Texas 78712, U.S.A. and $b$ Farmakologiska Institutionen, Karolinska Institutet, Stockholm, Sweden

Eight analogs of substance $P$ (SP) were synthesized by an automated solid phase-technique. Three analogs are undecapeptides, as is SP, and five are heptapeptides. $\mathrm{Phe}^{7}$ of $\mathrm{SP}$ is significant for activity, but $\mathrm{Phe}^{8}$ is not. Gly ${ }^{\theta}$ of $\mathrm{SP}$, when replaced by $D-L e u$, resulted in a desirable loss of activity toward the design of antagonists. Three of the five heptapeptides have single D-amino acid substitution, and the other two have two D-amino acid substitutions. Those three heptapeptides, having a D-amino acid in the position corresponding to $\mathrm{Gly}^{\circ}$ of SP, had the desirable lowest agonist activity. [D-Phe ${ }^{7}$ ]SP had antagonist activity which was weak, probably because it also had low agonist activity.

The biological activity of substance $P$ (SP) was discovered in 1931 by von Euler and Gaddum. ${ }^{1}$ Chang and Leeman ${ }^{2}$ isolated a sialogogic peptide from bovine hypothalami, and found that the biological properties were indistinguishable from those described for substance $\mathbf{P}$. This peptide was sequenced by Chang et al. ${ }^{3}$ and synthesized by Tregear et al. ${ }^{4}$ and by Fisher et $a l . .^{5}$ A survey was published in $1976 .^{\circ}$

Some investigators have presumed substance $\mathbf{P}$ to be a neurotransmitter in sensory pathways.

* PH. 131.
In the mammalian gut, immunoreactivity of SP has been found in the nerve fibers of the outer smooth muscle layer. Immunoreactive endocrine cells are found in the epithelium." Such a distribution indicates that SP would have several sites of action in the gastrointestinal tract.

Chemically, SP has been classified with the tachikinins. Six naturally occurring tachikinins have been characterized from vertebrates and invertebrates as given in Scheme 1.

Since the sequences of eledoisin and that of physalemin were established in 1962, and 1964, respectively, by Erspamer et al..$^{2,10}$ a large number of synthetic analogs related to these two tachikinins and later to SP had been synthesized and biologically studied before the advent of the sequence and synthesis of SP. Consequently, the literature on structure-activity relationships for the tachikinins is extensive; Erspamer et al.11

Bury and Mashford ${ }^{12}$ reviewed the pharmacology of substance $\mathbf{P}$ and its physiological roles, and included the activities of analogs, and a background on the sedative effect. Magnusson et $a l .{ }^{13}$ reported on the effect of substance $\mathbf{P}$ in monoamnergic mechanisms in the brain.
Arg-Pro-Lys-Pro-Gln-Gln-Phe-Phe-Gly-Leu-Met-NH $<$ Glu-Pro-Ser-Lys-Asp-Ala-Phe-Ile-Gly-Leu-Met-NH Asp-Val-Pro-Lys-Ser-Asp-Glu-Phe-Val-Gly-Leu-Met-NH $<$ Glu-Ala-Asp-Pro-Asn-Lys-Phe-Tyr-Gly-Leu-Met-NH ${ }_{2}$ $<$ Glu-Pro-Asp-Pro-Asn-Ala-Phe-Tyr-Gly-Leu-Met-NH ${ }_{2}$ $<$ Glu-Asn-Pro-Asn-Arg-Phe-Ile-Gly-Leu-Met-NH,
Substance $\mathbf{P}$

Eledoisin

Kassinin

Physalemin

Uperolein

Phyllomedusin

\section{Scheme 1.}


One of our goals is to achieve an effective inhibitor of substance P. There are no reliable guidelines to modify synthetically the agonist activity of a peptide hormone to give an effective inhibitor of the hormone. One may first study which amino acids of a peptide are essential for recognition, binding, and activation as such aspects are applicable to substance $P$. Since acquisition of knowledge on the receptorbound conformation is so difficult, the acquisition of biological data on analogs is a feasible initial study. The insertion of D-amino acids was emphasized in the research by many investigators on antagonists of the luteinizing hormone-releasing hormone (LH-RH), ${ }^{14}$ and it was found that such substitutions at critical positions in the sequence of LH-RH could confer antagonistic activity. Since it is known that heptapeptides are essentially as active as the undecapeptide sequence of SP, we have synthesized three undercapeptides and five heptapeptides with emphasis on D-amino acids for conformational aspects, and have tested them for agonist and antagonist activity.

\section{BIOLOGICAL METHODS}

The activities of the synthetic analogs and the activity of substance $P$ were compared using the terminal portion of the guinea pig ileum in an organ bath (Table 1). Concentrationresponse curves were obtained by adding the analog cumulatively so that the concentration in the bath was increased by a factor of 2 whenever a steady response to the previous concentration had been reached. In the tests for antagonistic activity, the analog of substance $P$ was added $10 \mathrm{~min}$ before substance $P$ was added. The details of the protocol for studies emphasizing antagonistic activity will be described after this research, to achieve an effective antagonist has further progressed, but the basis of the method is evident from the published details of the assay for agonist activity.

\section{CHEMICAL METHODS AND MATERIALS}

Amino acids and the BHA resins were purchased from Beckman Inc., Palo Alto, Calif., and from Bachem Inc., Marina de Rey, Calif. For amino acid analyses, samples were hydrolyzed in $6 \mathrm{~N} \mathrm{HCl}$ in evacuated sealed glass ampoules at $110^{\circ} \mathrm{C}$ for $18 \mathrm{~h}$. The hydrolysate was evaporated to a residue which was dissolved in a sodium citrate buffer ( $\mathrm{pH}$ 2.2). This solution was injected into a Beckman 119 Amino Acid Analyzer equipped with an Infotronics Model CRS-210 digital integrator. After the initial amino acid is coupled to the benzhydrylamine (BHA) resin, the product is used without amino acid analysis when the test with ninhydrin is negative. The BHA resin as purchased was specified to contain 0.47 mequ. $\mathrm{N} / \mathrm{g}$.

During chromatography-fractionation on Sephadex monitoring was carried out at $254 \mathrm{~nm}$ using an ISCO UV monitor. The fractions of the major peak were checked for purity by TLC using the best system for each peptide. Those fractions showing only one spot by TLC were combined and lyophilized. The yield was sacrificed for the purity of the fractions selected.

Table 1. Data on agonist and antagonist activities.

No. Compound

Potency $^{a}$

Antagonist activity con., $1^{-6} 0 \mathrm{M}^{\mathrm{b}}$

(V)

(VI)

(VIII) Lys-Gln-Phe-Ile-D-Phe-Leu-Met-NH

Arg-Pro-Lys-Pro-Gln-Gln-Phe-Phe-Gly-Leu-Met-NH ${ }_{2}$ (Substance P)

Arg-Pro-Lys-Pro-Gln-Gln-D-Phe-Phe-Gly-Leu-Met- $\mathrm{NH}_{2}$ [D-Phe ${ }^{7}$ ]-SP

Arg-Pro-Lys-Pro-Gln-Gln-Phe-Phe-D-Leu-Leu-Met-NH $\mathrm{NH}_{2}$ [D-Leu']-SP

Arg-Pro-Lys-Pro-Gln-Gln-D-Phe-D-Phe-Gly-Leu-Met$\mathrm{NH}_{2}$ [D-Phe ${ }^{7}, \mathrm{D}-\mathrm{Phe}^{8}$ ]-SP

$<$ Glu-GIn-Phe-Phe-D-Leu-Leu-Met-NH, $<$ Glu-Gln-D-Phe-Phe-Gly-Leu-Met-NH ${ }_{2}$

$<$ Glu-Gln-D-Phe-D-Phe-Gly-Leu-Met-NH

100

2

pos.

0.5

n.t.

0.3

$<0.02$

0.25

0.11

$<0.06$

$<0.07$

n.t.

neg.

neg.

neg.

neg.

neg.

${ }^{a}$ Relative to SP isolated from guinea pig ileum. ${ }^{b}$ pos., positive; n. t., not tested, neg., negative. 
Table 2. Program for double deprotection and DCC coupling.

\begin{tabular}{|c|c|c|}
\hline Reagents & Operations & $\underset{(\min )}{\operatorname{Mix}}$ Time \\
\hline $\begin{aligned} & \text { 1. } \mathrm{CH}_{2} \mathrm{Cl}_{2} \\
& \text { 2. } \mathrm{TFA}\left(30 \% \text { in } \mathrm{CH}_{2} \mathrm{Cl}_{2}\right) \\
& \text { 3. } \mathrm{TFA} \\
& \text { 4. } \mathrm{CH}_{2} \mathrm{Cl}_{2}, \text { i-Prop, } \mathrm{CH}_{2} \mathrm{Cl}_{2} \\
& 5 . \mathrm{TFA} \\
& 6 . \mathrm{TFA} \\
& \text { 7. } \mathrm{CH}_{2} \mathrm{Cl}_{2}, \text { i-Prop, } \mathrm{CH}_{2} \mathrm{Cl}_{2} \\
& \text { 8. } \mathrm{Et}_{3} \mathrm{~N}\left(10 \% \text { in } \mathrm{CH}_{2} \mathrm{Cl}_{2}\right) \\
& \text { 9. } \mathrm{Ft}_{3} \mathrm{~N} \\
& \text { 10. } \mathrm{BocAA}\left(\text { in } \mathrm{CH}_{2} \mathrm{Cl}_{2} \text { or } \mathrm{DMF}\right) \\
& \text { 11. } \mathrm{DCC}\left(10 \% \text { in } \mathrm{CH}_{2} \mathrm{Cl}_{2}\right) \\
& \text { 12. } \mathrm{CH}_{2} \mathrm{Cl}_{2}, \mathrm{DMF} \text { and } \mathrm{CH}_{2} \mathrm{Cl}_{2} \\
&\end{aligned}$ & $\begin{array}{l}3 \times \text { Wash } \\
\text { Prewash } \\
\text { Deprotection } \\
3 \times \text { Wash each } \\
\text { Prewash } \\
\text { Double deprotection } \\
3 \times \text { Wash each } \\
2 \times \text { Prewash } \\
\text { Neutralization } \\
\text { Delivery, transfer, and mix } \\
\text { Delivery and mix } \\
3 \times \text { Wash } \\
\end{array}$ & $\begin{array}{r}2 \\
2 \\
30 \\
2 \\
2 \\
30 \\
2 \\
2 \\
5 \\
2 \\
180-600\end{array}$ \\
\hline
\end{tabular}

Homogenity of the peptides was demonstrated by thin-layer chromatography on silica gel plates, using the following six solvent systems: $R_{F}{ }^{1}, \mathrm{n} \cdot \mathrm{BuOH}-\mathrm{EtOAc}-\mathrm{AcOH}-\mathrm{H}_{2} \mathrm{O}$ (1:1:1:1); $\quad R_{F}{ }^{2}, \quad$ EtOAc-pyridine-AcOH- $\mathrm{H}_{2} \mathrm{O}$ (5:5:1:3); $R_{F}{ }^{8}, \mathrm{n}-\mathrm{BuOH}$ - pyridine - $\mathrm{AcOH}-\mathrm{H}_{2} \mathrm{O}$ (30:30:6:24); $R_{F}{ }^{4}$, i-Prop-1 N AcOH (2:1); $\mathrm{R}_{F}{ }^{5}$, $\mathrm{CHCl}_{3}$ - conc $\mathrm{NH}_{4} \mathrm{OH}-\mathrm{CH}_{3} \mathrm{OH}(60: 20: 45), \mathrm{R}_{F}^{6}$, $\mathrm{n}-\mathrm{BuOH}-\mathrm{EtOAc}-\mathrm{AcOH}-\mathrm{H}_{2} \mathrm{O} \quad(2: 2: 1: 1)$. The peptide spots were detected with the ninhydrin and chlorine - o-tolidine reagents. When single spots were observed for a peptide in all six chromatographic systems, the sample was considered appropriately pure for bioassay. These $R_{F}$ data were reinforced by the amino acid analytical data.

The analogs were synthesized by the solid. phase method ${ }^{15,16}$ using a Beckman Model 990 Peptide Synthesizer. The BHA resin ${ }^{17}$ was used as a solid support.

The $\alpha$-amino functions were protected by the tert Boc group, except for the Aoc group for $A r g$, and the $\mathbf{Z}$ group for < Glu. The first Bocamino acid was coupled as follows to the BHAresin (0.47 mequ. N/g). The BHA-resin hydrochloride was treated with a solution of $25 \%$ (by volume) triethylamine in methylene chloride $(25 \mathrm{ml} / \mathrm{g}$ of resin) for $10 \mathrm{~min}$. Then, it was washed with $25 \mathrm{ml}$ methylene chloride per gram. For one gram of the resin, 2.5 mequ. of the $C$. terminal Boc-amino acid and DCC were used. The quantitation of coupling reaction was revealed by a negative ninhydrin color test. ${ }^{18}$ When the ninhydrin test was positive, even after 3 or 4 couplings, the unreacted amino groups were blocked by acetylation. ${ }^{10}$ The side chain functionalities were protected by Tosyl (Arg) and 2-Cl-Z (Lys).

For the coupling reactions, using $10 \%$ DCC in methylene chloride, the amino acid derivatives were dissolved in methylene chloride, except the Aoc-Arg (Tos) and the $Z<$ Glu which were dissolved in DMF (distilled over ninhydrin). For the coupling of Gln, the active ester, Boc-Gln-ONp, dissolved in DMF (distilled over ninhydrin) was used.

Double deprotection and DCC coupling were programed as given in Table 2: For double coupling, a program without steps $1-6$ was used. The active ester coupling was performed with a program without step 11. A 2.5-fold excess of the amino acid derivative was used for the first coupling and one equivalent was used for the second DCC-coupling. A three-fold excess of Boc-Gln-ONp was used for the first active ester single coupling, and a two-fold excess was used for the double coupling. Coupling times usually ranged from 3 to 5 hours for the DCC, and 10 to 12 hours for the active ester coupling.

The protected peptide resin was simultaneously cleaved and deblocked with anhydrous (dried over $\mathrm{CoF}_{3}$ ) liquid $\mathrm{HF}$ containing $10-$ $20 \%$ anisole. ${ }^{20}$ Approximately $10 \mathrm{ml}$ of liquid $\mathrm{HF}$ was used for $1 \mathrm{~g}$ resin, and the reaction time was $1 \mathrm{~h}$ at $0^{\circ} \mathrm{C}$. The $\mathrm{HF}$ was removed under reduced pressure. Then the peptide-resin mixture was washed with ethyl acetate and the peptide was extracted with either 1 or $10 \%$ acetic acid. After lyophylization, the crude peptide was purified. 


\section{PURIFICATION OF THE PEPTIDES}

[D-Leu']-SP (II) (Arg-Pro-Lys-Pro-Gln-GlnPhe-Phe-D-Leu-Leu-Met- $\mathrm{NH}_{2}$ ). Two grams of BHA-resin (HCl-salt) afforded $2.7 \mathrm{~g}$ of Boc-GlnPhe-Phe-D-Leu-Leu-Met-BHA, and $1.2 \mathrm{~g}$ of this resin was used for the preparation of $1.7 \mathrm{~g}$ of Aoc-Arg(Tos)-Pro-Lys(2-Cl-Z)-Pro-Gln-GlnPhe-Phe-D-Leu-Leu-Met-BHA resin. Cleavage by $\mathrm{HF}$ gave $410 \mathrm{mg}$ of the crude peptide, and a portion of $150 \mathrm{mg}$ was purified by partition chromatography on Sephadex G-25 with $0.1 \%$ $\mathrm{AcOH}$ - n-BuOH - pyridine, (10:7:3), and $61 \mathrm{mg}$ of the pure peptide was obtained. Amino acid analysis: Glu $1.22 \times 2$, Pro $1.05 \times 2$, Met 0.91 , Leu $0.95 \times 2$, Phe $0.87 \times 2$, Lys 0.92 , Arg 0.90 ; $R_{F}$ values: $R_{F}{ }^{1}=0.16, R_{F}^{2}=0.52, R_{F}^{8}=0.61$, $R_{F}{ }^{4}=0.04, R_{F}{ }^{5}=0.17$.

[D-Phe ${ }^{7}$-SP (I) (Arg-Pro-Lys-Pro-Gln-Gln-DPhe-Phe-Gly-Leu-Met-NH $\mathrm{N}_{2}$ ). Two grams of BHA-resin (HCl salt) were used to prepare $2.86 \mathrm{~g}$ of Boc-Gln-D-Phe-Phe-Gly-Leu-MetBHA resin. From $1.36 \mathrm{~g}$ of this hexapeptide resin, $1.77 \mathrm{~g}$ of Aoc-Arg(Tos)-Pro-Lys(2-ClZ)-Pro-Gln-Gln-D-Phe-Phe-Gly-Leu-Met-BHA resin was obtained. Cleavage by $\mathrm{HF}$ yielded 465 $\mathrm{mg}$ of the crude peptide. Purification by gelfiltration chromatography on Bio-Gel P2 with $1.3 \% \mathrm{AcOH}$ gave $356 \mathrm{mg}$ partially purified peptide. From $258 \mathrm{mg}$ of this material, by partition chromatography on Sephadex G-25 which was eluted with $0.1 \% \mathrm{AcOH}-\mathrm{n}$ $\mathrm{BuOH}$-pyridine (10:7:3), $187 \mathrm{mg}$ of pure [D.Phe ${ }^{7}$ ]-SP was obtained. Amino acid analysis: Glu $1.20 \times 2$, Pro $1.08 \times 2$, Gly 0.91, Met 0.90 , Leu 0.88, Phe $0.98 \times 2$, Lys 0.91 , Arg 0.90; $R_{F}$ values: $R_{F^{1}}=0.13, R_{F^{2}}=0.45, R_{F}^{8}=0.51$, $R_{F}{ }^{4}=0.04, R_{F}{ }^{5}=0.13$.

[D-Phe ${ }^{7}$, D-Phe ${ }^{8}$ ]-SP (III) (Arg-Pro-Lys-ProGln-Gln-D-Phe-D-Phe-Gly-Leu-Met- $\mathrm{NH}_{2}$ ). Three grams of BHA-resin (HCl salt) afforded $4.05 \mathrm{~g}$ of Boc-Gln-D-Phe-D-Phe-Gly-Leu-Met-BHA resin. From $1.9 \mathrm{~g}$ of this protected hexapeptide resin, $2.5 \mathrm{~g}$ of Aoc-Arg(Tos)-Pro-Lys (2-Cl-Z)Pro-GIn-Gln-D-Phe-D-Phe-Gly-Leu-Met-BHA

resin were obtained. Cleavage by $\mathrm{HF}$ gave $\mathbf{7 2 0}$ $\mathrm{mg}$ of crude peptide. A portion $(185 \mathrm{mg}$ ) of the peptide was subjected to a partition chromatog. raphy on Sephadex G-25 which was eluted with $0.1 \% \mathrm{AcOH}$ - n-BuOH - pyridine (10:7:3), and $10 \mathrm{mg}$ of the pure peptide was obtained. Amino acid analysis: Glu $1.18 \times 2$, Pro $1.07 \times 2$, Gly
0.93, Met 0.80, Leu 0.92, Phe $0.99 \times 2$, Lys 0.92 , Arg $0.89 ; R_{F}$ values: $R_{F}{ }^{1} 0.10, R_{F}{ }^{2}=0.44, R_{F}{ }^{3}=$ $0.51, R_{F}{ }^{4}=0.04, R_{F}^{5}=0.13$.

$<$ Glu-Gln-Phe-Phe-D-Leu-Leu-Met-NH $\mathrm{NH}_{2}$ (IV). $\mathrm{Z}<$ Glu was attached to $1.5 \mathrm{~g}$ of Gln-Phe-Phe. D-Leu-Leu-Met-BHA resin from the synthesis of (II), and $1.52 \mathrm{~g}$ of $\mathrm{Z}<$ Glu-Gln-Phe-Phe-DLeu-Leu-Met-BHA resin was obtained. After cleavage with HF, the peptide resin mixture was washed with ethyl acetate $(100 \mathrm{ml})$, then extracted with $10 \% \mathrm{AcOH}$ ( $100 \mathrm{ml})$, afterwards with the lower phase (100 ml) of $0.1 \% \mathrm{AcOH}-$ n-BuOH - pyridine (10:7:3), and at last with the upper phase $(100 \mathrm{ml})$ of $0.1 \% \mathrm{AcOH}-\mathrm{n}$. $\mathrm{BuOH}$-pyridine (10:7:3). From the extract with $10 \% \mathrm{AcOH}, 71 \mathrm{mg}$ crude peptide and from that of the lower phase of $0.1 \% \mathrm{AcOH}$ $\mathrm{n}-\mathrm{BuOH}$ - pyridine (10:7:3) $145 \mathrm{mg}$ of crude peptide were obtained. The extract of the upper phase of $0.1 \% \mathrm{AcOH}-\mathrm{n}-\mathrm{BuOH}-$ pyridine (10:7:3) yielded $23 \mathrm{mg}$ of the peptide. This fraction was pure in all TLC systems. Amino acid analysis: Glu $1.04 \times 2$, Met 0.85 , Leu $1.05 \times 2$, Phe $1.07 \times 2 ; R_{F}$ values: $R_{F^{1}}=0.78$, $R_{F^{2}}=0.93, \quad R_{F^{8}}=0.84, \quad R_{F}^{4}=0.79, \quad R_{F}^{5}=1.0$, $R_{F}{ }^{6}=0.70$.

< Glu-GIn-D-Phe-Phe-Gly-Leu-Met-NH $(\mathrm{V})$. Gln-D-Phe-Phe-Gly-Leu-Met-BHA resin (1.5 g) prepared in the synthesis of (I) was used to prepare $1.53 \mathrm{~g}$ of $\mathrm{Z}<$ Glu-Gln-D-Phe-Phe-GlyLeu-Met-BHA resin. Cleavage by HF yielded $370 \mathrm{mg}$ crude peptide. Purification by partition chromatography on Sephadex G-25 with $n$ $\mathrm{BuOH}-\mathrm{AcOH}-\mathrm{H}_{2} \mathrm{O}$ (4:1:5) gave $73 \mathrm{mg}$ of the pure peptide. Amino acid analysis: Glu $1.10 \times 2$, Gly 0.86 , Met 0.85 , Leu 0.89 , Phe $1.14 \times 2 ; R_{F}$ values: $R_{F}{ }^{1}=0.74, R_{F}{ }^{2}=0.89, R_{F}{ }^{3}=0.81, R_{F}{ }^{4}=$ $0.76, R_{F}^{5}=1.0, R_{F}^{6}=0.59$.

<Glu-Gln-D-Phe-D-Phe-Gly-Leu-Met-NH (VI). Gln-D-Phe-D-Phe-Gly-Leu-Met-BHA resin prepared in the synthesis of (III) was used to prepare $2.2 \mathrm{~g}$ of $\mathrm{Z}<$ Glu-Gln-D-Phe-D-Phe-GlyLeu-Met-BHA resin. Cleavage by HF yielded $310 \mathrm{mg}$ crude peptide, and $110 \mathrm{mg}$ of this material were purified by partition chromatography on Sephadex G-25 with n-BuOH - AcOH $-\mathrm{H}_{2} \mathrm{O}(4: 1: 5)$ to yield $75 \mathrm{mg}$ pure peptide. Amino acid analysis: Glu $1.19 \times 2$, Gly 0.88 , Met 0.85 , Leu 0.92 , Phe $1.06 \times 2 ; R_{F}$ values: $R_{F}^{1}=0.72, R_{F}^{3}=0.76, R_{F}{ }^{4}=0.74, R_{F}{ }^{5}=0.59$.

Lys-Gln-Phe-D-Leu-D-Phe-Leu-Met- $\mathrm{NH}_{2}$ (VII). From $1.5 \mathrm{~g}$ of BHA resin ( $\mathrm{HCl}$ salt) $1.9 \mathrm{~g}$

Acta Chem. Scand. B 33 (1979) No. 1 
of Boc-D-Phe-Leu-Met-BHA resin was prepared; $1.2 \mathrm{~g}$ of this product was used to prepare $1.32 \mathrm{~g}$ of Boc-Gln-Phe-D-Leu-D-Phe-Leu-MetBHA resin. A portion of $600 \mathrm{mg}$ of this protected peptide resin was used to obtain $630 \mathrm{mg}$ of Boc-Lys(2-Cl-Z)-Gln-Phe-D-Leu-D-Phe-LeuMet-BHA resin. Cleavage by HF resulted in $133 \mathrm{mg}$ of the crude peptide. It was purified by partition chromatography on Sephadex Gr-25 with the elute $0.1 \% \mathrm{AcOH}-\mathrm{n}-\mathrm{BuOH}-$ pyridine (10:7:3), and $70 \mathrm{mg}$ of partially purified peptide were recovered. Further purification of $40 \mathrm{mg}$ of this material on Sephadex LH-20 with $\mathrm{n}-\mathrm{BuOH}-\mathrm{H}_{2} \mathrm{O}-\mathrm{AcOH}$ (6:90:10) yielded $19.8 \mathrm{mg}$ of the pure peptide. Amino acid analysis: Glu 0.95, Met 0.93, Leu $1.08 \times 2$, Phe $1.05 \times$ 2, Lys $0.87 ; R_{F}$ values: $R_{F}{ }^{1}=0.78, R_{F}{ }^{2}=0.93$, $R_{F}^{3}=0.59, R_{F}^{3}=0.59, R_{F}^{5}=0.88, R_{F}^{6}=0.31$.

Lys-Gln-Phe-Ileu-D-Phe-Leu-Met-NH ${ }_{2}$ (VIII). Starting with $700 \mathrm{mg}$ of Boc-D-Phe-Leu-MetBHA resin, which was prepared for the synthesis of (VII), $770 \mathrm{mg}$ of Boc-Lys(2-Cl-Z)-Gln-PheIleu-D-Phe-Leu-Met-BHA resin were synthesized. Cleavage by HF yielded $167 \mathrm{mg}$ crude peptide. It was subjected to a partition chromatography on Sephadex G-25 with $0.1 \% \mathrm{AcOH}-$ $\mathrm{n}-\mathrm{BuOH}$-pyridine (11:5:3), and $55.7 \mathrm{mg}$ of partially purified peptide were recovered. Further purification with a second column G-25 using $0.1 \% \mathrm{AcOH}-\mathrm{n}-\mathrm{BuOH}$ - pyridine (10:7:3) yielded $47 \mathrm{mg}$ almost pure peptide. Another chromatography on LH-20 eluted with n$\mathrm{BuOH}-\mathrm{H}_{2} \mathrm{O}-\mathrm{AcOH} \quad(6: 90: 10)$ provided 43.6 $\mathrm{mg}$ of pure peptide. Amino acid analysis: Glu 1.04, Met 0.95, Ileu 0.87, Leu 0.98, Phe $1.09 \times 2$, Lys $0.99 . R_{F}$ values: $R_{F}{ }^{1}=0.75$, $R_{F^{2}}=0.93, R_{F}{ }^{3}=0.59, R_{F}^{5}=0.88, R_{F}{ }^{6}=0.28$.

\section{RESULTS AND DISCUSSION}

In analog I, the $\mathrm{Ph}^{7}$ of SP has been replaced with D-Phe ", and this undecapeptide had a relative activity of only $2 \%$ in comparison to SP showing again the importance of $\mathrm{Ph}^{7}$ in SP for biological activity. It is notable that Phe is in position 7 of 4 of the 6 tachikinins, and counting from the C-terminal, $\mathrm{Phe}$ is in position 5 of all 6 tachikinins.

In analog II, Gly ${ }^{\circ}$ of SP is replaced by D-Leu, and this substitution resulted in a very low activity $(0.5 \%)$. However, the substitution of $\mathrm{Gly}^{\circ}$ in eledoisin by certain $\mathrm{L}_{\text {-amino acids did }}$ not reduce the activity. ${ }^{21}$ The introduction of D-Leu into position 9 of SP may have resulted in a conformational change, which is particularly detrimental for activity.

In analog III, the $\mathrm{Phe}^{7}$-Phe ${ }^{8}$-moiety of SP has been replaced by $\mathrm{D}-\mathrm{Ph}^{{ }^{7}}$-D-Phe ${ }^{8}$; the relative activity of $0.3 \%$ confirms the importance of Phe in position 7 of SP and the relative unimportance of Phe in position 8, because analogs I and III have comparable low activities.

Analogs IV - VIII are heptapeptides, and analogs, IV, V, VIII contain one D-amino acid moiety, and analogs VI and VII contain two D-amino acid moieties.

The heptapeptides IV, VII and VIII, of the five heptapeptides, had comparable lowest agonist activities. In each of these three analogs of such low activity, the Gly ${ }^{9}$ of SP has been replaced with a $\mathrm{D}$-amino acid, either D-Leu or D-Phe. Consequently, position 9 as well as position 7 are important for continuing studies on agonist and antagonist activities.

In this research, structural substitutions to achieve substantial loss of agonist activity may be a desirable step toward effective antagonists, because effective antagonists may have very little, or no agonist activity. The design of an inactive analog of an agonist does not necessarily also provide an effective antagonist. However, Analog I, which is an undecapeptide with the important Phe ${ }^{7}$ of SP replaced by D-Phe ${ }^{\text {? }}$ did show antagonist activity, but the effect was weak. Such low antagonism may be expected, because this analog also showed agonist activity ( $2 \%$ ). These data may be a basis for the design of new analogs having agonist and antagonist activities.

Acknowledgements. Appreciation is expressed to the Robert A. Welch Foundation, the PHS National Heart and Lung Institute, Grant No. HL18993-02 and to the Swedish Medical Research Council (No. B79-04X-04495).

\section{REFERENCES}

1. von Euler, U.S. and Gaddum, J. H. $J$. Physiol. (London) 72 (1931) 74.

2. Chang, M. M. and Leeman, S. E. J. Biol. Chem. 245 (1970) 4784.

3. Chang, M. M., Leeman, S. E. and Niall, H. D. Nature, New Biol. 232 (1971) 86.

4. Tregear, G. W., Niall, H. D., Potts, J. T., Leeman, S. E. and Chang, M. M. Nature, New Biol. 232 (1971) 87. 
5. Fisher, G. H., Humphries, J., Folkers, K., Pernow, B. and Bowers, C. Y. J. Med. Chem. 17 (1974) 843.

6. von Euler, U. S. and Pernow, B. Substance $P$, Nobel Symposium, 37th, Stockholm 1976, Raven, New York.

7. Sundler, F., Hakanson, R., Larsson, L. J., Brodin, E. and Nilsson, G. Substance $P$, Nobel Symposium, 37th, Stockholm 1976, Raven, New York, p. 59.

8. Rosell, S., Björkroth, U., Chang, D., Yamaguchi, I., Wan, Y. P., Rackur, G., Fisher, G. and Folkers, $K$. Substance $P$, Nobel Symposium, 37th, Stockholm 1976, Raven, New York, p. 83.

9. Erspamer, V. and Anastasi, A. Experientia 18 (1962) 58.

10. Erspamer, V., Anastasi, A., Bertaccini, G. and Cei, J. M. Experientia 20 (1964) 489.

11. Erspamer, V., Erspamer, G. F. and Linari, G. Substance $P$, Nobel Symposium, 37th, Stockholm 1976, Raven, New York, p. 67.

12. Bury, R. W. and Mashford, M. L. The Aust. Exp. Med. Sci. 55 (1977).

13. Magnusson, T., Carlsson, A., Fisher, G. H., Chang, D. and Folkers, K. J. Neural Transm. 38 (1976) 89.

14. Corbin, A. and Beattie, C. W. Endocr. Res. Commun. 2 (1975) 1.

15. Merrifield, R. B. J. Am. Chem. Soc. 85 (1963) 2149.

16. Erickson, B. W and Merrifield, R. B. In The Proteins, Vol. II, 3rd Ed., Neurath, H., Hill, R. and Boeder, C. L., Eds., Acadomic, New York 1976.

17. Monahan, M. W. and Rivier, J. Biochem. Biophys. Res. Commun., 48 (1972) 1100.

18. Kaiser, E., Coloscott, R. L., Bossinger, C. D. and Cook, P. I. Anal. Biochem. 34 (1970) 595.

19. Markley, L. D. and Dotman, L. C. Tetrahedron Lett. 21 (1970) 1787.

20. Sakakibara, S., Shimonishi, Y., Kishida, Y., Okado, M. and Sugihara, H. Bull. Chem. Soc. Jpn. 40 (1967) 2164.

21. Bernardi, L., Bosisio, G., Chilemi, F., Se Caro, G., Castilione, R., Erspamer, V. Glaesser, A. and Goffredo, O. Experientia 20 (1964) 306.

Received July 18, 1978. 